\title{
Abnormal insulin secretion and glucose metabolism in pancreatic islets from the spontaneously diabetic GK rat
}

\author{
C.-G. Östenson ${ }^{1}$, A. Khan ${ }^{1}$, S.M.Abdel-Halim ${ }^{1}$, A. Guenifi ${ }^{1}$, K. Suzuki ${ }^{2}$, Y. Goto ${ }^{2}$ and S. Efendic ${ }^{1}$ \\ ${ }^{1}$ Department of Endocrinology, Karolinska Institute and Hospital, Stockholm, Sweden, and \\ ${ }^{2}$ Department of Medicine, Tohoku Kosei-nenkin Hospital, Sendai, Japan
}

\begin{abstract}
Summary. Insulin secretion and islet glucose metabolism were compared in pancreatic islets isolated from GK/Wistar (GK) rats with spontaneous Type 2 (non-insulin-dependent) diabetes mellitus and control Wistar rats. Islet insulin content was $24.5 \pm 3.1 \mu \mathrm{U} / \mathrm{ng}$ islet DNA in GK rats and $28.8 \pm 2.5 \mu \mathrm{U} / \mathrm{ng}$ islet DNA in control rats, with a mean $( \pm$ SEM) islet DNA content of $17.3 \pm 1.7$ and $26.5 \pm 3.4 \mathrm{ng}$ $(p<0.05)$, respectively. Basal insulin secretion at $3.3 \mathrm{mmol} / 1$ glucose was $0.19 \pm 0.03 \mu \mathrm{U} \cdot \mathrm{ng}$ islet $\mathrm{DNA}^{-1} \cdot \mathrm{h}^{-1}$ in GK rat islets and $0.40 \pm 0.07$ in control islets. Glucose $(16.7 \mathrm{mmol} / \mathrm{l})$ stimulated insulin release in GK rat islets only two-fold while in control islets five-fold. Glucose utilization at $16.7 \mathrm{mmol} / \mathrm{l}$ glucose, as measured by the formation of ${ }^{3} \mathrm{H}_{2} \mathrm{O}$ from [5${ }^{3} \mathrm{H}$ ]glucose, was 2.4 times higher in GK rat islets (3.1 \pm $0.7 \mathrm{pmol} \cdot \mathrm{ng}$ islet $\mathrm{DNA}^{-1} \cdot \mathrm{h}^{-1}$ ) than in control islets (1.3土 $0.1 \mathrm{pmol} \cdot \mathrm{ng}$ islet $\left.\mathrm{DNA}^{-1} \cdot \mathrm{h}^{-1} ; p<0.05\right)$. In contrast, glucose oxidation, estimated as the production of ${ }^{14} \mathrm{CO}_{2}$ from [U-
\end{abstract}

$\left.{ }^{14} \mathrm{C}\right]$ glucose, was similar in both types of islets and corresponded to $15 \pm 2$ and $30 \pm 3 \%(p<0.001)$ of total glucose phosphorylated in GK and control islets, respectively. Glucose cycling, i.e. the rate of dephosphorylation of the total amount of glucose phosphorylated, (determined as production of labelled glucose from islets incubated with ${ }^{3} \mathrm{H}_{2} \mathrm{O}$ ) was $16.4 \pm 3.4 \%$ in GK rat and $6.4 \pm 1.0 \%$ in control islets, respectively $(p<0.01)$. We conclude that insulin secretion stimulated by glucose is markedly impaired in GK rat islets. Glucose metabolism is also altered in GK rat islets, with diminished ratio between oxidation and utilization of glucose, and increased glucose cycling, suggesting links between impaired glucose-induced insulin release and abnormal glucose metabolism.

Key words: Type 2 (non-insulin-dependent) diabetes mellitus, pancreatic islets, perfused pancreas, glucose metabolism.
Type 2 (non-insulin-dependent) diabetes mellitus is characterized by impaired insulin response, insulin resistance or both [1]. As to the impaired insulin secretion, it remains unclear whether this is due to a defective stimulus-secretion coupling or an impaired secretory capacity, or both, of the beta cell $[2,3]$.

To throw light upon the latter question, several studies have been conducted in an experimental animal model of Type 2 diabetes, i.e. the neonatally streptozotocin-injected rat (nSTZ). In this non-obese, non-ketotic rat, both the glucose-induced insulin response [4-6] and insulin sensitivity are decreased $[4,6]$. Studies of glucose metabolism in islets of nSTZ rats have suggested that the glucose insensitivity of the beta cells in this model is due to at least two abnormalities. Thus, there is evidence of both increased glucose cycling [7], indicating increased dephosphorylation of glucose 6-phosphate, and decreased glucose oxidation [8], implying a beta-cell mitochondrial defect. Each of these abnormalities may interfere with the stimulus-secretion coupling by lowering of the intracellular ATP/ADP ratio [2].
The relevance of these putative mechanisms for the understanding of Type 2 diabetes in man has been questioned. First, in some studies on nSTZ rats the insulin response to glucose was less impaired in isolated islets than in the perfused pancreas, or in vivo $[4,9,10]$, making the results on glucose fluxes in isolated nSTZ islets less valid. Second, recent data have suggested that neonatal streptozotocin treatment might cause long-term damage to key mitochondrial dehydrogenases in pancreatic beta cells and their precursor cells [11].

With the aim of studying a spontaneous animal model of Type 2 diabetes, more suitable for studies of insulin release and islet metabolism in vitro, we have examined the GK (Goto-Kakizaki) rat. This is a non-obese, mildly diabetic rat which was developed by inbreeding Wistar rats with selection of rats in each generation with the highest blood glucose levels during an oral glucose tolerance test $[12,13]$. By the sixth generation $\left(\mathrm{F}_{5}\right)$ of GK rats glucose intolerance was evident. Simultaneously, in the perfused pancreas the first phase of glucose-induced insulin response was markedly impaired while the second 
phase was preserved [12]. A recent investigation in $\mathrm{F}_{37}-\mathrm{F}_{39}$ generations of GK rats has indicated further impairment of the insulin response to glucose [14]. In the present study, we have characterized the model at generations $\mathrm{F}_{42}-\mathrm{F}_{43}$ with a glucose tolerance test in vivo, and the kinetics of glucose-induced insulin secretion were studied in the isolated, perfused pancreas. Beta-cell responsiveness in the perfused pancreas was compared to that in isolated pancreatic islets of GK rats. Furthermore, islet glucose metabolism was assessed by measurements of utilization, oxidation and cycling of glucose.

\section{Materials and methods}

\section{Breeding of $G K$ rats}

The Stockholm colony of GK rats started with five pairs of GK rats $\left(F_{40}\right)$ obtained from Tohoku University School of Medicine, Sendai, Japan, in August 1989. These rats, weighing 200-300 g, were mildly hyperglycaemic after fasting ovemight (blood glucose levels $9.6 \pm 0.5$ and $7.2 \pm 0.4 \mathrm{mmol} / \mathrm{l}$ in males and females, respectively). All rats had free access to tap water and a standard pelleted diet (ALAB, Sollentuna, Sweden). A 12 -h light and dark cycle (06.00 to 18.00 hours) was strictly enforced. Inbreeding resulted in litters with 3-8 surviving pups, which were kept with their lactating mother until weaning after 28 days.

\section{Glucose tolerance test}

In 2-month-old male rats, an intraperitoneal glucose tolerance test was performed. A glucose solution ( $2 \mathrm{~g} / \mathrm{kg}$ body weight) was injected i.p. and the blood glucose concentration was determined at $0,15,30$, 60 and $120 \mathrm{~min}$ in blood obtained after tail-vein incision by a glucose oxidase method using reagent strips (BM-test glycemie 1-44; Boehringer Mannheim GmbH, Mannheim, FRG) read for absorbance in a reflectance meter (Reflolux II; Boehringer Mannheim).

\section{Isolated, perfused pancreas}

Studies in the isolated perfused pancreas were performed using male GK rats aged 2-3 months, weighing approximately $250 \mathrm{~g}$. After anaesthetization (pentobarbital i.p.; $100 \mathrm{mg} / \mathrm{kg}$ ), the pancreata were dissected free from adjacent tissues [15] and placed in a perfusion chamber. The basal perfusion medium consisted of Krebs-Ringer bicarbonate solution supplemented with bovine albumin $(20 \mathrm{~g} / \mathrm{l})$ and glucose $(3.3 \mathrm{mmol} / 1)$. The medium was fed via a cannula in the aorta into the isolated pancreas by an open, non-recycling perfusion system with a flow rate of $2.8 \mathrm{ml} / \mathrm{min}$. After a 30 -min equilibration period with basal medium, the glucose concentration was raised to $16.7 \mathrm{mmol} / \mathrm{h}$ at time zero and maintained for $20 \mathrm{~min}$, finally followed by a $10-\mathrm{min}$ period with basal medium $(3.3 \mathrm{mmol} / 1$ glucose; $\mathrm{min} 20$ min 30). Samples of the perfusate were collected in pre-chilled tubes, at the time intervals indicated, for radioimmunoassay of insulin [16].

\section{Experiments with isolated islets}

Pancreatic islets were isolated aseptically by collagenase digestion [17] from 200-250 g male control and GK rats. Islets intended for studies of insulin release were either used directly or maintained overnight at $37^{\circ} \mathrm{C}$, in a gas phase of $5 \% \mathrm{CO}_{2}$ in air, in plastic tissue culture dishes each containing $5 \mathrm{ml}$ RPMI 1640 (Flow Laboratories Ltd., Irvine, UK) with $11.1 \mathrm{mmol} / \mathrm{l}$ glucose and $10 \%$ heat-inactiv- ated newborn calf serum. Islets destined for determinations of glucose metabolism, were used directly.

Islet insulin content was determined by radioimmunoassay in batches of three islets homogenized by sonication and extracted overnight at $+4{ }^{\circ} \mathrm{C}$ in $200 \mu \mathrm{l}$ of acid ethanol ( $70 \%$, volume/volume). Islet DNA content was assayed in batches of five islets with a fluorometric method as modified by Hinegardner [18]. The sensitivity of this method was $30 \mathrm{ng}$ DNA per sample.

Insulin secretion was measured in static incubations. Batches of three islets were incubated for $60 \mathrm{~min}$ at $37^{\circ} \mathrm{C}$ in tubes containing $300 \mu \mathrm{l}$ of Krebs-Ringer bicarbonate (KRB) buffer solution, $\mathrm{pH} 7.4$, supplemented with $2 \mathrm{mg} / \mathrm{ml}$ bovine serum albumin (fraction V; Sigma Chemical Co., St Louis, Mo., USA), $10 \mathrm{mmol} / \mathrm{l}$ HEPES (Sigma) and different glucose concentrations $(3.3,5.5,8.3,11.1$ and $16.7 \mathrm{mmol} / 1)$. Incubations were preceded by a 30 -min pre-incubation period at $3.3 \mathrm{mmol} / 1$ glucose. After incubation, a sample of the medium was used for radioimmunoassay of insulin.

Glucose utilization was determined as described [7, 19] from the yield of ${ }^{3} \mathrm{H}_{2} \mathrm{O}$ from batches of 15 islets incubated for $180 \mathrm{~min}$ in $\mathrm{KRB}$, supplemented as above plus $16.7 \mathrm{mmol} / \mathrm{lglucose}$ and $0.6 \mathrm{mCi} / \mathrm{mmol}$ $\left[5^{-3} \mathrm{H}\right]$ glucose (Amersham International, Amersham, Bucks, UK). Glucose oxidation was measured at the formation of ${ }^{14} \mathrm{CO}_{2}$ from batches of 15 islets incubated for $180 \mathrm{~min}$ in $\mathrm{KRB}$ at $16.7 \mathrm{mmol} / \mathrm{/}$ glucose and $1.2 \mathrm{mCi} / \mathrm{mmol}\left[\mathrm{U}_{-}^{14} \mathrm{C}\right] \mathrm{glucose}$ (Amersham) [17].

Glucose cycling was estimated in batches of 100 islets incubated at $16.7 \mathrm{mmol} / \mathrm{glucose}$ and ${ }^{3} \mathrm{H}_{2} \mathrm{O}(5 \mathrm{mCi} / 100 \mu \mathrm{l} ;$ Amersham $)$. After a 180 -min incubation at $37^{\circ} \mathrm{C}, 100 \mu 1$ of $10 \%$ perchloric acid was added into the vial. Then $2.5 \mathrm{mg}$ glucose was added, and the supernatant was neutralized with $\mathrm{KOH}$ and centrifuged. The supernatant was passed through a mixed bed ion exchange resin (MB-3; BDH

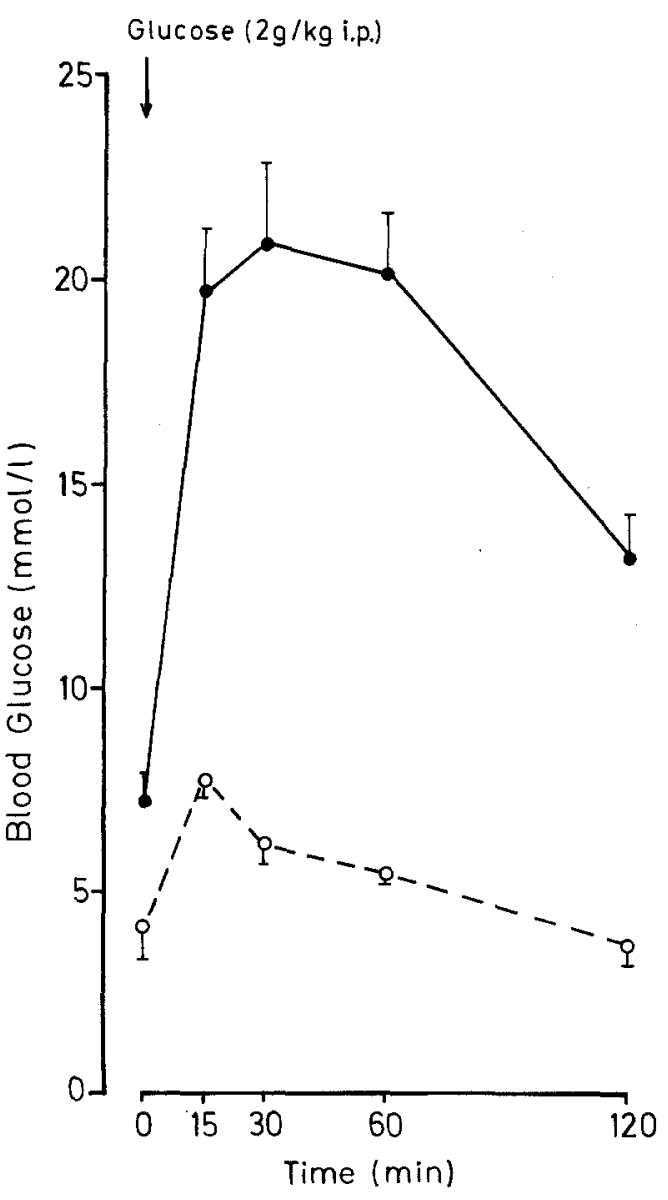

Fig.1. Glucose tolerance as tested with an i.p. injection of glucose $(2 \mathrm{~g} / \mathrm{kg}$ body weight $)$ in non-diabetic control $(0 ; n=15)$ and diabetic GK $(\bullet ; n=13)$ rats. Mean \pm SEM 


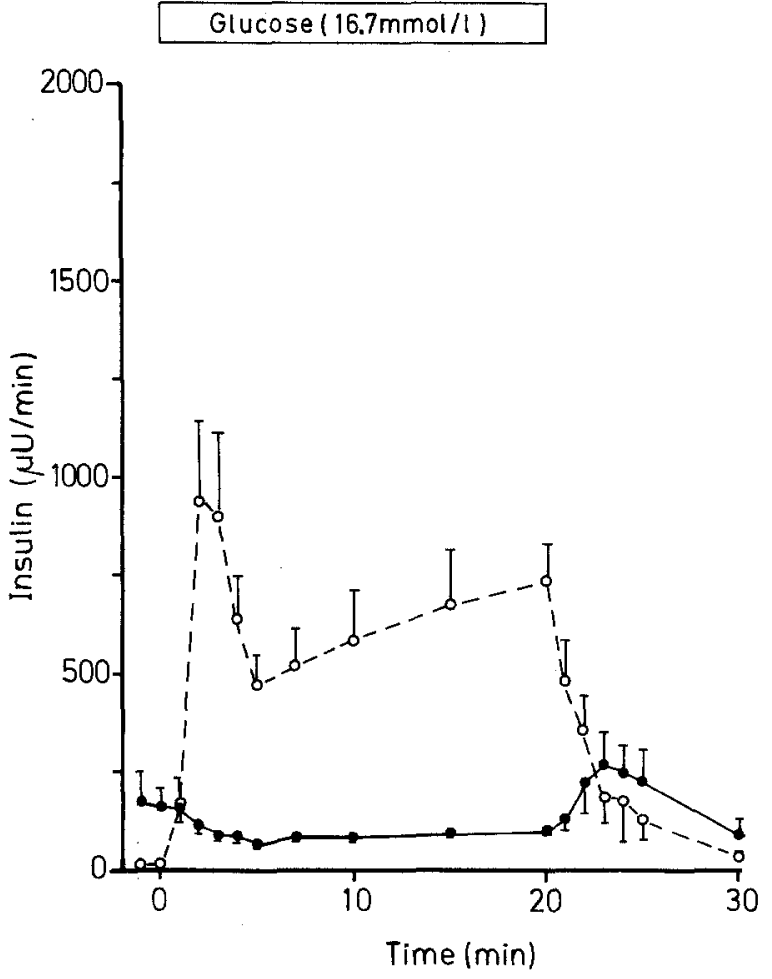

Fig. 2. Insulin responses to $16.7 \mathrm{mmol} / \mathrm{l}$ glucose in the perfused pancreas of male non-diabetic control $(0---0 ; n=6)$ and diabetic GK $(\bullet ; n=6)$ rats. Results (mean $\pm \mathrm{SEM}$ ) are given as $\mu \mathrm{U}$ of insulin released per min

Ltd, Poole, UK) and the effluent freeze dried. The residue was dissolved in water and evaporated three times to remove all ${ }^{3} \mathrm{H}_{2} \mathrm{O}$ from the incubation medium. The medium was then dissolved in $\mathrm{H}_{2} \mathrm{O}$ and put on HPLC (HPX-87P System; Bio-Rad, Richmond, Calif., USA) column to separate glucose. The amount of ${ }^{3} \mathrm{H}$ incorporated into glucose was determined as previously described [7]. Glucose cycling was calculated as per cent glucose dephosphorylated of the total of phosphorylated glucose.

\section{Statistical analysis}

Results are expressed as mean \pm SEM, and significance of differences was assessed by Student's $t$-test for unpaired or paired data, as appropriate. A $p$ value $<0.05$ was considered statistically significant.

\section{Results}

Animals. Glucose tolerance was studied in 2-month-old male GK and control rats after an overnight fasting period. Fasting blood glucose was significantly higher in GK than in control Wistar rats $(7.2 \pm 0.7$ vs $4.1 \pm 0.8 \mathrm{mmol} / \mathrm{l}$, $p<0.05$; Fig. 1). After injection i.p. of a glucose solution $(2 \mathrm{~g} / \mathrm{kg})$, blood glucose levels in control rats increased to a maximum of less than $8 \mathrm{mmol} / \mathrm{l}$ after $15 \mathrm{~min}$, and then subsequently decreased to fasting levels after $120 \mathrm{~min}$. In GK rats, the glucose injection caused a rapid increase in blood glucose to a plateau of approximately $20 \mathrm{mmol} / \mathrm{l}$. After $120 \mathrm{~min}$, blood glucose concentrations in GK rats were still almost twice the fasting level.
GK and control rats selected for islet studies had similar body weights ( $235 \pm 6 \mathrm{~g}, n=13$, and $231 \pm 5 \mathrm{~g}, n=15$, respectively). Non-fasting blood glucose concentrations were $11.7 \pm 1.7$ and $6.1 \pm 0.3 \mathrm{mmol} / 1$ in these GK and control rats, respectively.

Insulin release from the perfused pancreas. In the perfused pancreas of control rats, glucose $(16.7 \mathrm{mmol} / \mathrm{l})$ elicited a biphasic response of insulin (the total incremental response being $11.9 \pm 2.0 \mathrm{mU} / 20 \mathrm{~min}$ ) (Fig.2). In pancreata of GK rats, basal insulin release (at $3.3 \mathrm{mmol} / 1$ glucose) was significantly increased $(168 \pm 62$ vs $16 \pm 3 \mu \mathrm{U} / \mathrm{min}$ in control rats, $p<0.01$ ). During perfusion with $16.7 \mathrm{mmol} / \mathrm{l}$ glucose, insulin release was not stimulated but rather tended to be inhibited $(-1.2 \pm 0.8 \mathrm{mU} / 20 \mathrm{~min})$, and after omission of the high glucose concentration a transient increase in insulin release was observed.

Characterization of islets. Islet DNA content in GK islets was $65 \%$ of that of control islets ( $p<0.05$; Table 1 ), while the content of insulin in GK islets was $64 \%$ of that in control islets $(p<0.01)$, when expressed on a per islet basis. Thus, when taking into account the lower DNA content of GK islets, the insulin content per ng of islet DNA was similar in both types of islets.

Insulin release from isolated islets. In control islets, glucose stimulated insulin release in a dose-dependent manner (Fig. 3). At $16.7 \mathrm{mmol} / \mathrm{l}$ glucose the insulin response was increased five-fold as compared to the response at $3.3 \mathrm{mmol} / 1$ glucose. In GK rat islets, the insulin response was severely impaired at all glucose concentrations used (Fig. 3). The defect in insulin secretion in GK rat islets was similar in non-cultured and cultured islets (Table 2).

Islet glucose metabolism. The amount of ${ }^{3} \mathrm{H}$ incorporated into glucose was six-fold higher in GK rat than in control islets incubated in the presence of $16.7 \mathrm{mmol} / \mathrm{lglucose}$ and ${ }^{3} \mathrm{H}_{2} \mathrm{O}$ (Table 3). Islet glucose utilization, determined as the production of ${ }^{3} \mathrm{H}_{2} \mathrm{O}$ from $\left[5-{ }^{3} \mathrm{H}\right]$ glucose, was 2.4 -fold higher in GK rat than in control islets. Thus, the total phosphorylated glucose, i.e. the amount of glucose 6phosphate being metabolized in glycolysis or dephosphorylated to glucose by glucose 6-phosphatase, was enhanced almost three times in GK islets (Table 3 ). Following these data, the percent of total phosphorylated glucose being dephosphorylated (glucose cycling) was significantly increased in GK vs control islets $(p<0.01)$. Glucose oxidation rates, estimated as the production of ${ }^{14} \mathrm{CO}_{2}$ from $\left[\mathrm{U}-{ }^{14} \mathrm{C}\right]$ glucose, were not significantly different between GK and control islets. The ratio between glucose oxidation and total glucose phosphorylation rates was

Table 1. Islet insulin and DNA contents

\begin{tabular}{lll}
\hline Estimation & $\begin{array}{l}\text { Control islets } \\
(n=7)\end{array}$ & $\begin{array}{l}\text { GK islets } \\
(n=7)\end{array}$ \\
\hline DNA content (ng/islet) & $26.5 \pm 3.4$ & $17.3 \pm 1.7^{\mathrm{a}}$ \\
Insulin content $(\mu \mathrm{U} /$ islet) & $746 \pm 32$ & $\begin{array}{l}477 \pm 63^{\mathrm{b}} \\
\text { Insulin content }(\mu \mathrm{U} / \mathrm{ng} \text { islet DNA) }\end{array}$ \\
\hline
\end{tabular}

Mean \pm SEM.

${ }^{\mathrm{a}} p<0.05$ and ${ }^{\mathrm{b}} p<0.01$ vs control 


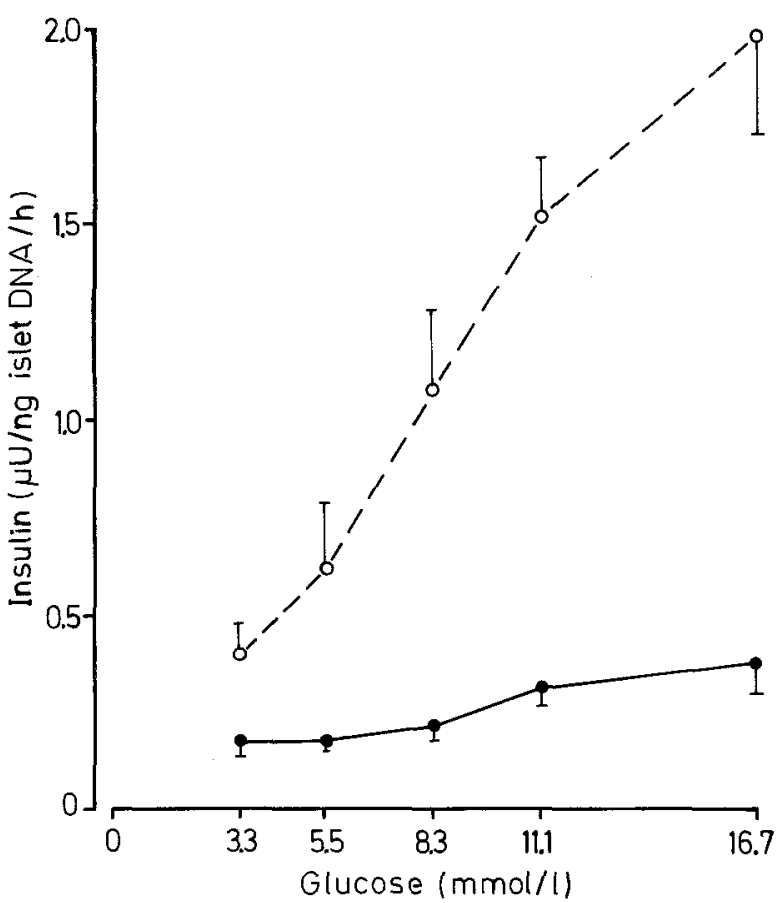

Fig.3. Glucose dependency of insulin release from pancreatic islets isolated from non-diabetic control $(0 ; n=6)$ and diabetic GK $(\bullet ; n=6)$ rats. Results (mean $\pm \mathrm{SEM}$ ) are expressed as $\mu \mathrm{U}$ of insulin released per ng islet DNA content per $h$

only $15 \pm 2 \%$ in GK rat islets compared to $30 \pm 3 \%$ in control islets $(p<0.001)$.

\section{Discussion}

As evident from the intraperitoneal glucose tolerance tests, the GK rats relative to control rats had significantly higher fasting blood glucose levels. Immediately after glucose injection a prolonged plateau of marked hyperglycaemia was reached in GK rats, suggesting an impaired insulin response.

Kimura et al. [12] found that the insulin response to $16.7 \mathrm{mmol} / \mathrm{l}$ glucose in the perfused pancreas of the sixth $\left(F_{5}\right)$ generation of GK rats was markedly impaired. A further deterioration was noted in $\mathrm{F}_{8}$ rats, where the glucosestimulated insulin response was about $10 \%$ of that in control rats. Portha and co-workers [14] studied insulin release in perfused pancreata from $F_{37}-F_{39}$ GK rats. In their experiments, each pancreas was perfused with glucose-free medium prior to stimulation with $16.7 \mathrm{mmol} / 1$ glucose. In these studies glucose transiently suppressed basal insulin release, while discontinuation of glucose from the perfusion medium resulted in an "off-response", i.e. an increased insulin secretion. The inhibitory effect of glucose on insulin release in these animals could be due to a transient drop in the cytoplasmic concentration of ATP, reflecting increased consumption of ATP during the glucose phosphorylation process [20]. This drop in ATP would in turn induce increased activity of the ATP sensitive $\mathrm{K}^{+}$-channels, hyperpolarization of the beta-cell mem- brane, a decrease in cytosolic calcium and inhibition of insulin release [21].

In our experiments with $\mathrm{F}_{42}-\mathrm{F}_{43}$ generations of $\mathrm{GK}$ rats, $16.7 \mathrm{mmol} / \mathrm{l}$ glucose not only transiently but also continuously suppressed insulin release and, as in Portha's experiments, discontinuation of perfusion with $16.7 \mathrm{mmol} / \mathrm{l}$ glucose resulted in an increase of insulin secretion. Since in our experiments $3.3 \mathrm{mmol} / 1$ glucose was present in the basal perfusion medium, it is not likely that the suppression of insulin release by glucose could be accounted for by a decrease in ATP. In this connection, it is interesting that similar paradoxical insulin responses to glucose were also described in the perfused pancreas of neonatally streptozotocin-diabetic (nSTZ) rats and nondiabetic rats made hyperglycaemic by $48-96 \mathrm{~h}$ of glucose infusion [4].

A second explanation of the paradoxical insulin response to glucose in the GK pancreas was offered by Hellman et al. [22], suggesting an abnormal regulation by glucose of the cytosolic calcium in the diabetic beta-cell. Finally, Malaisse [23] has considered this inhibitory effect of glucose on basal insulin release in diabetes as the consequence of an increased glycogen accumulation in the beta cell and the "anomeric malaise". Thus, when sufficient glycogen is present in the beta-cell, the glucose-induced decrease in glycogenolysis may exceed the rate of utilization of the exogenous hexose, resulting in a transient and

Table 2. Glucose-induced insulin release from non-cultured and cultured islets

\begin{tabular}{lllll}
\hline $\begin{array}{l}\text { Glucose } \\
\text { concentration } \\
(\text { mmol/l) }\end{array}$ & \multicolumn{2}{l}{ Non-cultured islets } & & \multicolumn{2}{l}{ Cultured islets } \\
\cline { 2 - 3 } \cline { 5 - 6 } & $\begin{array}{l}\text { Control } \\
(n=5)\end{array}$ & GK $(n=5)$ & $\begin{array}{l}\text { Control } \\
(n=6)\end{array}$ & GK $(n=6)$ \\
\hline 3.3 & $0.32 \pm 0.07$ & $0.19 \pm 0.02$ & $0.40 \pm 0.07$ & $0.19 \pm 0.04$ \\
16.7 & $1.97 \pm 0.24^{\mathrm{a}}$ & $0.30 \pm 0.05^{\mathrm{b}}$ & $2.01 \pm 0.26^{\mathrm{a}}$ & $0.38 \pm 0.05^{\mathrm{b}}$ \\
\hline
\end{tabular}

Results (mean $\pm \mathrm{SEM}$ ) are expressed as $\mu \mathrm{U}$ of insulin released per $\mathrm{ng}$ islet DNA per $\mathrm{h}$ from either non-cultured islets or islets cultured overnight at $11.1 \mathrm{mmol} / 1$ glucose.

${ }^{\mathrm{a}} p<0.001$ and ${ }^{\mathrm{b}} p<0.05 \mathrm{vs} 3.3 \mathrm{mmol} / \mathrm{l}$ glucose

Table 3. Glucose metabolism in GK and control rat islets

\begin{tabular}{|c|c|c|}
\hline Estimation & $\begin{array}{l}\text { Control islets } \\
(n=7)\end{array}$ & $\begin{array}{l}\text { GK islets } \\
(n=6)\end{array}$ \\
\hline $\begin{array}{l}{ }^{3} \mathrm{H} \text { incorporated into glucose }(\mathrm{A}) \\
\text { (picoatom } \cdot \mathrm{ng} \text { islet } \mathrm{DNA}^{-1} \cdot \mathrm{h}^{-1} \text { ) }\end{array}$ & $0.09 \pm 0.01$ & $0.56 \pm 0.10^{a}$ \\
\hline $\begin{array}{l}\text { Glucose utilization (B) } \\
\left(\text { pmol } \cdot \mathrm{ng} \text { islet } \mathrm{DNA}^{-1} \cdot \mathrm{h}^{-1}\right)\end{array}$ & $1.28 \pm 0.11$ & $3.12 \pm 0.66^{b}$ \\
\hline $\begin{array}{l}\text { Total glucose phosphorylation }(\mathrm{C}) \\
\left(\mathrm{A}+\mathrm{B} ; \mathrm{pmol} \cdot \mathrm{ng} \text { islet } \mathrm{DNA}^{-1} \cdot \mathrm{h}^{-1}\right)\end{array}$ & $1.37 \pm 0.11$ & $3.68 \pm 0.64^{b}$ \\
\hline $\begin{array}{l}\text { Glucose cycling } \\
(100 \cdot \mathrm{A} / \mathrm{C} ; \%)\end{array}$ & $6.4 \pm 1.0$ & $16.4 \pm 3.4^{b}$ \\
\hline $\begin{array}{l}\text { Glucose oxidation (D) } \\
\left(\text { pmol } \cdot \text { ng islet } \mathrm{DNA}^{-1} \cdot \mathrm{h}^{-1}\right)\end{array}$ & $0.40 \pm 0.05$ & $0.54 \pm 0.07$ \\
\hline $\begin{array}{l}\text { Ratio glucose oxidation/total } \\
\text { glucose phosphorylation } \\
(\mathrm{D} / \mathrm{C} ; \%)\end{array}$ & $30 \pm 3$ & $15 \pm 2^{\mathrm{a}}$ \\
\hline
\end{tabular}

Mean \pm SEM.

${ }^{\mathrm{a}} p<0.001,{ }^{\mathrm{b}} p<0.01$ vs control islets 
paradoxical decrease in glycolytic flux and, therefore, insulin release.

Although glucose-stimulated insulin release was totally abolished in the perfused GK pancreas, it was minute but significant in isolated GK islets; the mean response at $16.7 \mathrm{mmol} / \mathrm{l}$ glucose being twice that at $3.3 \mathrm{mmol} / 1$ glucose. Similarly, in previous studies with nSTZ rats insulin release from isolated islets was enhanced about five-fold by glucose, while the response was nearly abolished in the perfused pancreas $[4,8-10]$. It is not clear why beta-cells respond better to glucose in the isolated islets than in the perfused pancreas in diabetic animals. It has been speculated that, in addition to beta-cell insensitivity to glucose in the perfused pancreas, some other factor carried by circulation contributed to the inhibition of insulin responsiveness $[4,9]$. Since the insulin content of GK islets is similar to that of control islets, as expressed per islet DNA content, the impairment of insulin response seems not to be due to decreased stores of the hormone. In support of this, we have found a normal insulin content in pancreata of 2-monthold GK rats (unpublished data).

Interestingly, basal insulin release was augmented ten fold in the perfused pancreas but decreased in isolated islets of GK rats as compared to non-diabetic rats. The reason for this difference is not known. A possible expla nation is that prolonged hyperglycaemia in the diabetic animals markedly potentiates basal insulin release in vivo and in the perfused pancreas, while the procedure of islet isolation, at $5.5 \mathrm{mmol} / \mathrm{l}$ glucose, diminishes such an effect of hyperglycaemia on basal insulin release.

It is generally accepted that glucose metabolism in the beta-cell plays a key role in the regulation of the stimulus-secretion coupling [2]. Metabolism of glucose increases ATP levels, resulting in increased insulin release. In the islets of nSTZ rats, decreased oxidative capacity has been evidenced [8], while glucose utilization was unchanged or mildly perturbed as compared to control islets $[4,7,8]$. However, we have found an increased glucose cycling, i.e. percent dephosphorylation of total phosphorylated glucose [7]. For every molecule of glucose turning in the glucose cycle, one molecule of ATP is consumed. Thus, in addition to reduced oxidation of glucose, an increased glucose cycling contributes to a decreased intracellular ATP/ADP ratio, which may constitute a cellular impairment leading to decreased insulin response in $\mathrm{nSTZ}$ islets.

In GK islets, in contrast to nSTZ islets, glucose utilization was 2.5 times higher, while glucose oxidation was normal as compared to control islets. However, the rate of glucose cycling was similar in GK and nSTZ islets, amounting to 16.4 and $15.7 \%$, respectively. An increased glucose utilization with preserved glucose oxidation, as found in GK islets, may be a consequence of an increased anaerobic glucose metabolism. The oxidation of NADH then occurs at an increased rate of lactate production, yielding the NAD required for further augmentation of the anaerobic glycolysis. Hypothetically, an impaired glycerol phosphate shuttle, resulting in decreased oxidation of $\mathrm{NADH}$, may be a primary event triggering an increased anaerobic glycolysis. Incidently, studies in
nSTZ rats have suggested that impairment of the glycerol phosphate shuttle is an important early defect in islets, leading to impaired beta-cell responsiveness to glucose [24].

Acknowledgements. This study was supported by grants from the Swedish Medical Research Council (00034), the Swedish Diabetes Association, the Nordic Insulin Foundation, Magn Bergvalls Foundation, Torsten and Ragnar Söderberg Foundations, and Sven and Ebba-Christina Hagbergs Foundation. The skillful technical assistance of Ms M. Sundén, Ms K. Warensjö and Ms A. Nylén is gratefully acknowledged.

\section{References}

1. Efendic S, Luft R, Wajngot A (1984) Aspects of the pathogenesis of type 2 diabetes. Endocr Rev 5: 395-410

2. Efendic S, Berggren P-O, Khan A, Östenson C-G (1991) Aspects of insulin release in NIDDM. In: Rifkin H, Colwell JA, Taylor SI (eds) Diabetes 1991. Elsevier Sci, Amsterdam, pp 169-172

3. Porte D Jז (1991) $\beta$-cells in type II diabetes mellitus. Diabetes 40 : $166-180$

4. Weir GC, Leahy JL, Bonner-Weir S (1986) Experimental reduction of b-cell mass: implications for the pathogenesis of diabetes. Diabetes Metab Rev 2: 125-161

5. Grill V, Westberg M, Östenson C-G (1987) B-cell insensitivity in a rat model of non-insulin-dependent diabetes. Evidence for a rapidly reversible effect of previous hyperglycemia. J Clin Invest 80: $664-669$

6. Blondel O, Bailbe D, Portha B (1989) Relation of insulin deficiency to impaired insulin action in NIDDM adult rats given streptozotocin as neonates. Diabetes 38: 610-617

7. Khan A, Chandramouli V, Östenson C-G, Löw H, Landau BR, Efendic S (1990) Glucose cycling in islets from normal and diabetic rats. Diabetes 39: 456-459

8. Portha B, Giroix M-H, Serradas P et al. (1988) Insulin production and glucose metabolism in isolated pancreatic islets of rats with NIDDM. Diabetes 37: 1226-1233

9. Grill V, Östenson C-G (1988) The influence of a diabetic state on insulin secretion: studies in animal models of non-insulin dependent diabetes. In: Grill V, Efendic S (eds) Pathogenesis of non-insulin-dependent diabetes mellitus. Raven Press, New York, pp 93-106

10. Halban PA, Bonner-Weir S, Weir GC(1983) Elevated proinsulin biosynthesis in vitro from a rat model of non-insulin-dependent diabetes mellitus. Diabetes 32: 277-281

11. Malaisse WJ, Giroix M-H, Zähner D, Marynissen G, Sener A, Portha B (1991) Neonatal streptozotocin injection: a model of glucotoxicity? Metabolism 40: 1101-1105

12. Kimura K, Toyota T, Kakizaki M, Kudo M, Takebe K, Goto $Y$ (1982) Impaired insulin secretion in the spontaneous diabetic rats. Tohoku J Exp Med 137: 453-459

13. Goto Y, Suzuki K, Sasaki M, Ono T, Abe S (1988) GK rat as a model of nonobese, noninsulin-dependent diabetes. Selective breeding over 35 generations. In: Shafrir E, Renold AR (eds) Frontiers in diabetes research. Lessons from animal diabetes II. John Libbey, London, pp 301-303

14. Portha B, Serradas P, Bailbe D, Suzuki K, Goto Y, Giroix M-H (1991) $\beta$-cell insensitivity to glucose in the GK rat, a spontaneous nonobese model for type II diabetes. Diabetes 40: 486-491

15. Loubatières AL, Mariani MM, Ribes G, de Malbosc H, Chapal J (1969) Étude expérimentale d'un nouveau sulfamide hypoglycémiant particulièrement actif, le HB419 ou glibenclamide. Diabetologia $5: 1-10$

16. Herbert V, Lau KS, Gottlieb CW, Bleicher SJ (1965) Coated charcoal immunoassay of insulin. J Clin Endocrinol Metab 25: 1375-1384 
17. Östenson C-G, Grill V (1986) Differences in long-term effects of $\mathrm{L}$-glutamine and $\mathrm{D}$-glucose on insulin release from rat pancreatic islets. Mol Cell Endocrinol 45: 215-221

18. Hinegardner RT (1971) An improved fluorometric assay for DNA. Anal Biochem 39: 197-201

19. Ashcroft SJH, Weerasinghe LCC, Bassett JM, Randle PJ (1972) The pentose cycle and insulin release in mouse pancreatic islets. Biochem J 126: 525-532

20. Malaisse WJ, Hutton JC, Kawazu S, Herchuelz A, Valverde I, Sener A (1979) The stimulus-secretion coupling of glucose-induced insulin release. XXXV. The links between metabolic and cationic events. Diabetologia 16: 331-341

21. Arkhammar P, Nilsson T, Rorsman P, Berggren P-O (1987) Inhibition of ATP-regulated $\mathrm{K}^{+}$channels precedes depolarizationinduced increase in cytoplasmic free $\mathrm{Ca}^{2+}$ concentration in pancreatic $\beta$-cells. J Biol Chem 262:5448-5454

22. Hellman B, Berne C, Grapengiesser E, Grill V, Gylfe E, Lund P-E (1990) The cytoplasmic $\mathrm{Ca}^{2+}$ response to glucose as an indi- cator of impairment of the pancreatic $\beta$-cell function. Eur J Clin Invest 20: S10-S17

23. Malaisse WJ (1991) The anomeric malaise: a manifestation of $\beta$-cell glucotoxicity. Horm Metab Res 23: 307-311

24. Giroix M-H, Rasschaert J, Bailbe D et al. (1991) Impairment of glycerol phosphate shuttle in islets from rats with diabetes induced by neonatal streptozotocin. Diabetes 40: 227-232

Received: 18 May 1992

and in revised form: 25 August 1992

Dr. C.-G.Östenson

Department of Endocrinology

Karolinska Hospital

PO Box 60500

S-104 01 Stockholm

Sweden 